\title{
United Nations accuses Iraq of military use
}

\section{Washington}

EVIDENCE of Iraq's use of chemical weapons has been produced by a team of experts sent to Iran by the United Nations (UN). In a report issued last week, the team said that it had examined a number of unexploded or damaged bombs in the war zone in Iran, all of which were designed to carry liquid, and that samples collected from one of the bombs proved upon analysis in Swedish and Swiss laboratories to be mustard gas. Soil and liquid samples provided to the team by Iranian forces and said to have come from a leaking bomb at another site in the war zone were found to contain the nerve gas tabun, also known as GA.

The UN team also examined Iranian soldiers at four hospitals in Iran; all 35 in the first group examined showed symp-

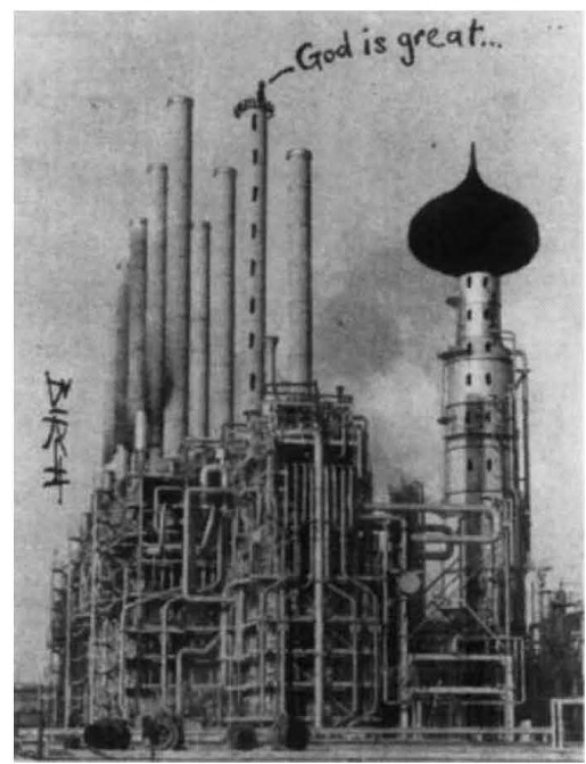

toms that the team said could be caused only by vesicant agents such as mustard gas. These symptoms included large areas of reddened and blistered skin, conjunctivitis and low white blood cell count. A second group of six patients was examined following the reported attack from which the GA sample was obtained; this group showed signs of nerve-gas poisoning, including respiratory problems, vomiting, tremors and acute miosis (contraction of the pupils). According to analyses run by the Iranian hospital staff, two of the six had very low acetylcholinesterase levels in their blood.

The US State Department says that it has known since late last year that Iraq has been manufacturing and using chemical weapons. It says that after quiet persuasion failed, it made its charges public in early March. A State Department official said last week that besides GA and mustard gas, Iraq is also now attempting to produce $\mathrm{GB}$, or sarin, a nerve agent which is considerably more lethal than either of the other two. (The US Army considers both GA and mustard gas to be obsolete but does stock GB).

Mustard gas is easily manufactured in one step from thiodiglycol and hydrochloric acid. GA is also relatively easy to produce; it requires a two-step synthesis using the materials ethanol, dimethylamine, potassium cyanide and phosphorous oxychloride. Sophisticated facilities, such as those used in advanced pesticide plants, are however needed to protect the workers in a plant producing GA. All of the nerve agents are chemically related to organophosphorous pesticides.

The bomb casings used in Iraq to deliver the chemical agents appear to be of a standard US pattern. The UN team reported that all the bombs it examined were identical; green, with a $10-\mathrm{cm}$ yellow band around the nose, and the marking " $\mathrm{BR} 250$ WP'". The team said that the thinness of the bomb casings - 1 to $2 \mathrm{~mm}$ - indicated that they were not intended for use as highexplosive bombs.

According to Tom Gervasi, an expert on the arms trade who runs the Center for Military Research and Analysis in New York, the markings and dimensions of the bomb correspond to a standard 250-pound US bomb used for white phosphorus hence the marking "WP". Gervasi noted that many other NATO countries also manufacture the bomb casings. White phosphorus, an incendiary, is normally

packed in thin-walled casings; the casing is effective for dispersing chemical agents as well.

The mustard gas samples were also analysed for mycotoxins - the fungal toxins that the United States claims have been used by Soviet and Soviet-backed forces in Afghanistan and South-East Asia - but none was detected. Press reports in recent weeks have claimed that Iraq was using these "yellow rain" toxins as well as chemicals. Dr Aubin Heyndrickx of the Ghent Toxicological Institute, Belgium, added credence to these reports by announcing that he had detected mycotoxins in the tenth of a part per million (p.p.m.) range in blood samples drawn from Iranian soldiers being treated in Vienna.

Heyndrickx's claims have, however, been greeted by other scientists with considerable scepticism - scepticism that has been fuelled by Heyndrickx's assertion that scientists at Sweden's National Defence Research Institute have confirmed his results. In fact, the Swedish scientists vigorously deny that they have been able to detect any mycotoxins in the samples they have looked at. The UN findings on mycotoxins were based on thin-layer chromatography, which has a detection limit of 5 p.p.m.

Although the UN report seems to leave little doubt that chemical weapons have been used, it is careful not to draw any conclusions about who is responsible. And the possibility, however remote, of fabrication of evidence by Iran has not yet been completely ruled out.

The UN team was made up of Dr Gustav Andersson of Sweden's National Defence Research Institute, Dr Manuel Dominguez of Spain's Army Medical Corps, Dr Peter Dunn of Australia's Defence Department Materials Research Laboratories, and Colonel Ulrich Imobersteg, chief of Switzerland's chemical defence division.

Stephen Budiansky

\section{Arms control advisers wanted}

\section{Los Angeles}

THE Carnegie Corporation of New York has just awarded Stanford University's Center for International Security and Arms Control a four-year grant to train two or three young scientists a year in the art of giving advice to government on arms control. Dr Sidney Drell, a co-director of the centre and deputy director of the Stanford Linear Accelerator, will run the project.

The objective is to fill the gap left by the ageing of the small group of scientists who, since the Manhattan Project, have been dispensing advice to presidents, the military and Congress on how to control the arms race. "We have not in my judgement been getting enough young scientists involved in arms control', Dr Drell says.

Like a handful of others from his generation, Dr Drell, now 57, was first invited to advise the government on arms control in the early 1960s. But more recently, he says, fewer young scientists have been given a chance to apply scientific knowledge to security issues. And while the huge cadre of defence scientists working directly for the government do excellent work, Drell says, the need that independent scientists should be working on defence issues is more important than ever.

Drell thinks others among the "older generation'" of experts - people like Hans Bethe, Jerome Wiesner, Paul Doty, Frank Long and Harvey Brooks - will also seek out younger scientists to train in the ort of arms control. Leading centres for such work are at Harvard University, Massachusetts Institute of Technology, Comell University, the University of California at Los Angeles and Stanford University. Sandra Blakeslee 